\title{
Mainstreaming Biodiversity for Food and Nutrition into Policies and Practices: Methodologies and Lessons Learned from Four Countries
}

\author{
Daniela BELTRAME ${ }^{1} \quad$ Eliot GEE ${ }^{1} \quad$ Birgul GUNER ${ }^{2}$ \\ Nina O. LAURIDSEN ${ }^{l} \quad$ W. L. Gamini SAMARASINGHE $\quad$ Victor W. WASIKE \\ Danny HUNTER ${ }^{1}$ Teresa BORELLI ${ }^{1}$ * \\ ${ }^{1}$ Bioversity International, Via dei Tre Denari 472/a, Rome/ITALY \\ ${ }^{2}$ General Directorate of Agricultural Research and Policies. Ankara/TURKEY \\ ${ }^{3}$ Plant Genetic Resources Center Gannoruwa, Peradeniya/SRI LANKA \\ ${ }^{4}$ Genetic Resources Research Center Nairobi/KENYA \\ * Corresponding author (Sorumlu yazar): t.borelli@cgiar.org \\ Received (Geliş tarihi): 25.01.2018Ａccepted (Kabul tarihi): 27.11.2018
}

\begin{abstract}
This paper outlines the methodology for mainstreaming biodiversity developed by the Biodiversity for Food and Nutrition Project (BFN), a multi-country initiative led by Brazil, Kenya, Sri Lanka and Turkey. BFN explored the nutritional properties of traditional and/or neglected native edible species, both wild and cultivated (including varieties and landraces), and used this knowledge to incorporate local agricultural biodiversity into national and global policy instruments that address food and nutrition security through the promotion of healthy, diversified and sustainable diets. Across the four countries, the project adopted a three-pillar approach for mainstreaming biodiversity for food and nutrition into policies and practices by: 1) Providing Evidence, 2) Influencing Policy, and 3) Raising Awareness. Case study examples from Brazil, Kenya, Turkey, and Sri Lanka demonstrate how the approach can be adapted to suit specific country contexts and how a multi-level, cross-sectoral partnership-based approach can create an enabling environment for mainstreaming biodiversity to improve nutrition.
\end{abstract}

Keywords: Biodiversity, traditional and neglected edible species, multi-country, policymaking, nutrition, mainstreaming.

\section{INTRODUCTION}

A number of global initiatives - chief among them the Convention on Biological Diversity (CBD) have recognised the nexus between biodiversity, agriculture and nutrition and have been calling, as far back as 2006 CBD, COP 8 Decision VIII/23 (Anonymous, 2006), for greater mainstreaming of agricultural biodiversity into policies and practices targeting food and nutrition security (Hunter et al., 2015; Anonymous, 2016a) as well as increased coordination between the environment, agriculture and nutrition sectors. The same global conventions acknowledge the potential of biodiversity to help meet various Sustainable Development Goals (SDGs), especially those linked to food systems
(Anonymous, 2016b), as it is evident that global improvements in food production are failing to meet human nutrition needs (Anonymous, 2017a) and to feed the planet in a healthy, sustainable and environmentally-friendly manner (Anonymous, 2015a). The latest Global Nutrition Report (Anonymous, 2017b) shows that, despite global progress in reducing malnutrition, $88 \%$ of countries for which data exist are confronting high economic and health costs linked to diet-related illnesses and malnutrition. According to the report, 2 billion people lack key micronutrients like iron and vitamin A, 155 million children are stunted while 2 billion adults are overweight or obese. The report also calls for increasing and maintaining 
diversity in production landscapes as a means of contributing to improved nutrition, resilience, productivity and climate change adaptation. However, limited examples exist for governments to put these recommendations into practice (Hunter et al., 2016).

Encouraging results from Bioversity International and others show that many of these collective issues can be addressed using agricultural biodiversity (Nugent, 2011; Remans and Smukler, 2013; Allen et al., 2014; Powell et al., 2015). Greater knowledge of the nutritional properties of these underutilised plant and animal species, increased policy support for their marketing and commercialisation, as well as increased awareness of their untapped potential for sustainable food and nutrition security, can contribute to furthering the achievement of many SDGs, as well as the Aichi Biodiversity Targets of the CBD. Agricultural efforts aimed at producing larger quantities of a few energy-rich staple crops (e.g. maize, wheat and rice) have gradually driven many nutritious species to disappear from people's diets and to fall into agricultural neglect, leading to huge losses in the diversity of foods available (Allen et al., 2014). The limited consumption of micronutrient-rich foods and the reduced ability of agricultural systems to provide the range of nutrients essential for human diets are key drivers of malnutrition (Johns and Eyzaguirre, 2006; Khoury et al., 2014). Research has shown that diet quality is often strongly linked to the number of species grown on farm (Remans et al., 2011; Romeo et al., 2016; Jones 2017; Koppmair et al., 2017), and the availability of food species in the wild (Broegaard et al., 2017). Furthermore, diversity on farm provides a range of environmental, economic, and social benefits to farming communities (Hajjar et al., 2008; Karabak, 2017) and is better adapted to local environments, including soils and climate (Stöber et al., 2016).

The Biodiversity for Food and Nutrition Project (BFN) is a six-year Global Environment Facility (GEF) funded initiative that connects the issues of food biodiversity conservation and sustainable use with critical food systems challenges. Prioritising nutrient-rich indigenous species, the BFN Project has spearheaded a partnership-based approach to research and mainstream agrobiodiversity into policies and practices in Brazil, Kenya, Turkey, and Sri Lanka. "Mainstreaming" refers to the process identified by the CBD as "embedding biodiversity considerations into policies, strategies and practices of key public and private actors that impact or rely on biodiversity so that it is conserved and sustainably used both locally and globally" (Huntley and Redford, 2014). By bringing together different sectors such as agriculture, finance, transport, market and trade, nutrition, health, education and social development, mainstreaming activity is meant to integrate biodiversity conservation and sustainable use into regional planning and development for the setting of global targets, national sectoral policies and frameworks, landscape management, and production and consumption practices. Methods can comprise of changes in policies, plans or laws, public-private partnerships or communication campaigns (Anonymous, 2017c), with attention to how this activity influences financial decisionmaking processes.

This paper draws on examples from the four target countries to outline the BFN methodology for mainstreaming biodiversity for food and nutrition into policies and programmes. The examples for each country demonstrate how the approach can be adapted and applied in a range of regions and contexts.

\section{MATERIALS AND METHODS}

Based on an analysis by the Leveraging Agriculture in South East Asia (LANSA) research partnership on measures to reduce malnutrition (Gillespie et al., 2013), the BFN Project framework (Figure 1) follows three overarching actions: providing evidence, influencing policy, and raising awareness. National project partners (Table 1) conducted activities in the three domains to garner support for neglected and underutilised species along the food value chain. On the supply side, capacity was built to analyse and recognise the value of this diversity and provide resources for its cultivation, conservation and use. On the demand side, the evidence generated by the project was communicated to consumers, who were made aware of the importance of biodiversity in nature and in diets, particularly in a local context, thereby influencing behaviour and perception including 
D. BELTRAME, E. GEE, B. GUNER, N. O. LAURIDSEN, W. L. G. SAMARASINGHE, V. W. WASIKE, D. HUNTER, T. BORELLI: MAINSTREAMING BIODIVERSITY FOR FOOD AND NUTRITION INTO POLICIES AND PRACTICES: METHODOLOGIES AND LESSONS LEARNED FROM FOUR COUNTRIES

dietary habits, appreciation of food culture and understanding of biodiversity. The project also offered a platform for cross-sectoral coordination among the different sectors that impact food and nutrition security (particularly the environment, agriculture, education and health sectors), thus creating an enabling environment for the project to operate in and paving the way for the integration of biodiversity for food and nutrition in policies and programmes.

Far from being linear in practice, the processes related to collecting evidence, influencing policies and raising awareness are more likely to happen in parallel and not necessarily in the suggested order. Partners took advantage of opportunities as they arose, guaranteeing that the approach was adapted to each new context. When considering how to adapt this methodology, helpful questions include: What platforms and policies already exist? How is biodiversity situated within the country's past and current food culture? What are major environmental and health challenges? At what scale (local, regional and national) is the model being applied? Perhaps the most variable and important factor is the nuanced process of establishing and coordinating productive partnerships. The knowledge and connections of the partners is ultimately one of the driving forces in achieving an understanding of the enabling environment in each country, and being able to implement mainstreaming activities.

\section{Country context}

The BFN approach has so far been implemented in four target countries, each with a different political environment, health status, traditional use of native species, and culture, though with similarities including both high biodiversity and malnutrition status. The following paragraphs give a brief overview of each context.

\section{Brazil}

Brazil has a wealth of underutilised natural biodiversity (approximately 18\% of global plant diversity) with the greatest number of endemic species on a global scale (Anonymous, 2016c). The country is also a major player in global agricultural production, yet malnutrition rates in the country are alarming. While a small part of the population remains undernourished $(<5 \%), 54 \%$ of the adult population is overweight and micronutrient deficiencies are prevalent, with $20 \%$ of women in reproductive age suffering from anaemia and $13 \%$ of preschool-age children diagnosed with Vitamin A deficiency (Anonymous, 2016d). Brazil carries the "triple burden of malnutrition", in which hunger, overweight and micronutrient deficiency coexist in

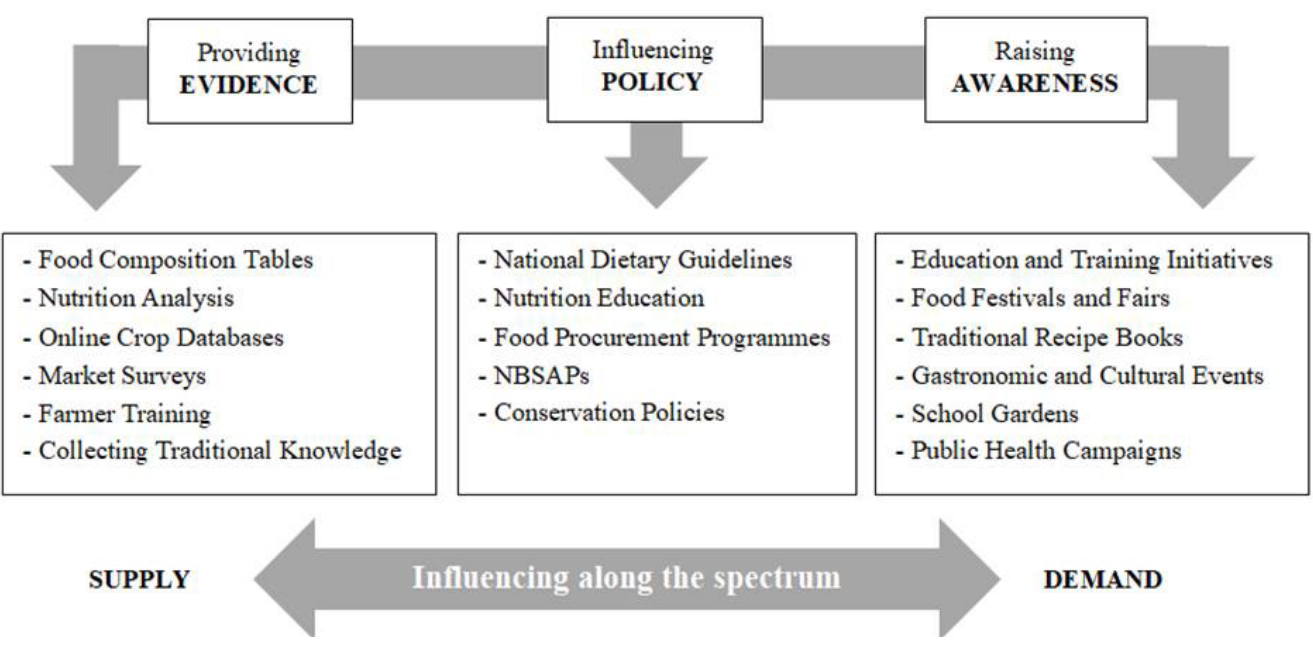

Figure 1. The BFN approach builds on three main pillars: Providing evidence, influencing policies, and raising awareness to mainstream biodiversity for food and nutrition. Through each of these, a number of activities can be done to mainstream biodiversity, all with an influence on aspects related to the supply and demand. See examples on some of the activities implemented through the BFN project in the figure. 
Table 1. The BFN project's national partners in Brazil, Kenya, Sri Lanka and Turkey.

\begin{tabular}{|c|c|c|c|c|}
\hline Key partners & Brazil & Kenya & Sri Lanka & Turkey \\
\hline $\begin{array}{l}\text { Political } \\
\text { partners }\end{array}$ & $\begin{array}{l}\text { - Ministry of Environment } \\
\text { (MMA) } \\
\text { - The National Food and } \\
\text { Nutrition Security } \\
\text { Council (CONSEA) } \\
\text { - Ministry for Agrarian } \\
\text { Development (MDA) } \\
\text { - Ministry of Social } \\
\text { Development and Fight } \\
\text { Against Hunger (MDS) } \\
\text { - Ministry of Agriculture, } \\
\text { Livestock and Food } \\
\text { Supply (MAPA) } \\
\text { - National Supply } \\
\text { Company (CONAB) } \\
\text { - Ministry of Education } \\
\text { (MEC) } \\
\text { - Ministry of Health (MS) }\end{array}$ & $\begin{array}{l}\text { - Ministry of Health (MoH) } \\
\text { - Division of Human } \\
\text { Nutrition and Dietetics } \\
\text { and National AIDS and } \\
\text { STI Control Programme } \\
\text { (NASCOP) } \\
\text { - Ministry of Agriculture - } \\
\text { Policy Department } \\
\text { - National Environment } \\
\text { Management Authority } \\
\text { (NEMA) }\end{array}$ & $\begin{array}{l}\text { - Ministry of Environment } \\
\text { (MOE) } \\
\text { - Ministry of Agriculture } \\
\text { (MOA) } \\
\text { - Ministry of Health and } \\
\text { Nutrition (MOHN) - Dept. of } \\
\text { Health (Nutrition } \\
\text { Coordination Division) and } \\
\text { Medical Research Institute } \\
\text { (MRI) } \\
\text { - The Forest Department (FD) } \\
\text { - Department of Animal } \\
\text { Production and Health } \\
\text { (DAPH) } \\
\text { - Ministry of Rural Industries } \\
\text { and Self Employment } \\
\text { - Ministry of agricultural } \\
\text { Development and Agrarian } \\
\text { Services - Dept. of } \\
\text { Agriculture (DOA) and } \\
\text { Dept. of Export Agriculture } \\
\text { (DEA) }\end{array}$ & $\begin{array}{l}\text {-Ministry of Agriculture and } \\
\text { Forestry (MAF) - General } \\
\text { Directorate of Agricultural } \\
\text { Research (TAGEM) } \\
\text {-Ministry of Agriculture and } \\
\text { Forestry - General Directorate } \\
\text { of Protection and Control } \\
\text { (KKGM) } \\
\text {-General Directorate of } \\
\text { Nature Protection and } \\
\text { National Parks } \\
\text {-Ministry of Health General } \\
\text { Directorate of Primary Health } \\
\text { Care Services } \\
\text {-Ministry of National } \\
\text { Education (MEB) } \\
\text {-Undersecretary of State } \\
\text { Planning Organization }\end{array}$ \\
\hline $\begin{array}{l}\text { Research } \\
\text { partners }\end{array}$ & $\begin{array}{l}\text { - Brazilian Agricultural } \\
\text { Research Corporation } \\
\text { (EMBRAPA) } \\
\text { - National Federation of } \\
\text { Nutritionists (FNN) } \\
\text { - São Paulo University } \\
\text { (USP) } \\
\text { - Campinas State } \\
\text { University (UNICAMP) }\end{array}$ & $\begin{array}{l}\text { - KALRO Socio- } \\
\text { Economics Division } \\
\text { - KALRO-Headquarters } \\
\text { Marketing Unit } \\
\text { - National Genebank of } \\
\text { Kenya (NGBK) } \\
\text { - KALRO-Kakamega } \\
\text { - Kenyatta University (KU) }\end{array}$ & $\begin{array}{l}\text { - Bandaranayake Memorial } \\
\text { Ayurvedic Research Institute } \\
\text { (BMARI) } \\
\text { - Dept. of National Botanic } \\
\text { Gardens (DNBG) } \\
\text { - University of Peradeniya, } \\
\text { Faculty of Agriculture } \\
\text { (FOAUP) } \\
\text { - University of Ruhuna } \\
\text { (Faculty of Agriculture) } \\
\text { - Wayamba University - Dept. } \\
\text { of Nutrition and Community } \\
\text { Resources Management } \\
\text { (NCRM) } \\
\text { - Institute of Fundamental } \\
\text { Studies (IFS) }\end{array}$ & $\begin{array}{l}\text {-Aegean Agricultural Research } \\
\text { Institute (ETAE) } \\
\text {-West Mediterranean } \\
\text { Agricultural Research } \\
\text { Institute (BATEM) } \\
\text {-Central Research Institute for } \\
\text { Field Crops (TARM) } \\
\text {-Bursa Food Control and } \\
\text { Central Research Institute } \\
\text {-The Scientific and } \\
\text { Technological Research } \\
\text { Council of Turkey } \\
\text { (TÜBiTAK) } \\
\text {-Erciyes University } \\
\text {-Selçuk University } \\
\text {-Gazi University } \\
\text {-Ege University } \\
\text {-Akdeniz University } \\
\text {-Ankara University } \\
\text {-Hacettepe University }\end{array}$ \\
\hline $\begin{array}{l}\text { NGOs, other } \\
\text { partners }\end{array}$ & $\begin{array}{l}\text { - Brazilian Biodiversity } \\
\text { Fund (FUNBIO) }\end{array}$ & $\begin{array}{l}\text { - National Museums of } \\
\text { Kenya (NMK) } \\
\text { - Rural Outreach } \\
\text { Programme }\end{array}$ & $\begin{array}{l}\text { - Biodiversity Secretariat } \\
\text { (BDS) } \\
\text { - Green movement Sri Lanka } \\
\text { (GMSL) } \\
\text { - Community Development } \\
\text { Centre (CDC) } \\
\text { - Saaraketha Lanka Pvt. Ltd. } \\
\text { - Sewalanka Foundation } \\
\text { Agriculture project }\end{array}$ & $\begin{array}{l}\text {-Turkish Association for the } \\
\text { Conservation of Nature and } \\
\text { Natural Resources (TTKD) } \\
\text {-Union of Turkish Chambers } \\
\text { of Agriculture } \\
\text {-Association of Turkish } \\
\text { Dieticians } \\
\text {-İstanbul Commodity } \\
\text { Exchange (ISTTiB) } \\
\text {-Alaçatı Art and Culture } \\
\text { Association }\end{array}$ \\
\hline
\end{tabular}

the same population and often in the same individual across the lifecycle (Anonymous, 2015b), conditions caused by diets low in variety and in nutrients. The combined effect of commercial agriculture focusing on a limited number of crops sugarcane, soybean, oranges, rice, coffee and maize - and changes in consumer preferences, dietary patterns and lifestyles has reduced food system diversity, meaning that there is less variety in the food available to consumers (Anonymous, 2009). Currently, only $24 \%$ of Brazilians consume the recommended $400 \mathrm{~g}$ (or more) per day of fruits and vegetables (Anonymous, 2018a). Food biodiversity is mostly managed by family farmers and traditional communities who own less than $25 \%$ of Brazil's agricultural land (França et al., 2009). 
D. BELTRAME, E. GEE, B. GUNER, N. O. LAURIDSEN, W. L. G. SAMARASINGHE, V. W. WASIKE, D. HUNTER, T. BORELLI: MAINSTREAMING BIODIVERSITY FOR FOOD AND NUTRITION INTO POLICIES AND PRACTICES: METHODOLOGIES AND LESSONS LEARNED FROM FOUR COUNTRIES

Although some of this native diversity is utilised such as cassava, passion fruit, and açaí - most species with potential nutritional and economic value remain unexplored. To reveal and take advantage of the hidden potential of Brazilian biodiversity, BFN partnered with national political institutions, universities, indigenous communities and celebrity chefs to further incorporate native crops into policies, markets, school curricula and other initiatives.

\section{Kenya}

Maize, beans, banana, rice and potatoes make up the bulk of the daily energy intake of a typical Kenyan household, yet many of the indigenous species present in Kenya, especially African leafy vegetables, have been shown to be nutritionally superior to these introduced crops both in terms of energy and micronutrient content (Hajjar et al., 2008). Native crops hold untapped potential to assist the $26 \%$ of Kenyan children who currently suffer from chronic undernutrition (resulting in impaired development and growth) as well as the sizeable portion $(4.1 \%)$, primarily in urban areas, who are overweight or obese. Widespread iodine deficiency disorders, iron deficiency (anaemia), and vitamin A and zinc deficiency $(49 \%$ of children under five years are vitamin A deficient) (Anonymous, 2016d) could be mitigated by more diverse diets. Unfortunately, a lack of organised market channels, poor agronomic practices, and low awareness regarding production, consumption and marketing of traditional plants creates barriers to improving nutrition status, food security and overall wellbeing in local households (Ngugi et al, 2006; Abukutsa-Onyango, 2007; Gido et al., 2017). To overcome some of these barriers, BFN has taken a localised approach in Busia County, where regional partners conducted plant research and coordinated school, policymaker, and farmer meetings to improve production and create an enabling policy and market environment for underutilised crops.

\section{Sri Lanka}

Sri Lanka is listed as one of the 35 biodiversity hotspots of the world and is home to around 4,500 edible species, of which 900 are endemic (Anonymous, 2016e). Sri Lankan farmers have maintained this rich diversity in crops and gardens for thousands of years, but urbanisation, deforestation, colonial influence and generational changes in food preferences and occupations have led to changes in food production and consumption habits, resulting in a population that carries the double burden of dietary-related disease (Rajapaksha, 1998). Despite recent gains in health and social status, $22 \%$ of the population remains undernourished and 34\% overweight or obese (Katulanda et al., 2010; Anonymous, 2017d). Using the BFN platform, Sri Lanka has revitalised research, conservation, and market-building efforts for nutritious and underutilised crops with activities that include establishing women-led traditional food businesses.

\section{Turkey}

Turkey is home to three of the world's 35 identified global biodiversity hotspots and contains almost 12,000 known species and sub-species of seed plants, of which 34\% are endemic and around 10\% identified as edible (Sekercioglu et al., 2011; Anonymous, 2014a; Ertug, 2014). Increasing urbanisation, habitat loss, and overexploitation threaten the unique growing grounds of many of these species, with the disappearance of endemic Mediterranean maquis, grasslands, coastal areas, wetlands, rivers, old growth forests, steppes and rangelands (Tan, 2010). Although Turkey has a tradition of harvesting and cooking edible wild plants (Tan and Taskin, 2011), their use is gradually dying out as young people migrate to urban areas and food collection from the wild is no longer possible or convenient. Furthermore, the popularity of varied traditional dishes is declining with younger generations who are attracted to more Western-style diets (Dogan, 2012). The varieties' continued conservation relies on renewing interest and knowledge of their consumption, and domesticating wild species to ensure sustainable use, which BFN has aimed to achieve through engagement with the private sector, building market capacity, and supporting initiatives in education and employment.

\section{RESULTS AND DISCUSSION}

This section is divided into three parts corresponding to the primary focus points of the 
project. Although the long-term impact of these actions cannot yet be measured, key examples demonstrate successful interventions in the respective countries.

\section{Providing evidence}

When insufficient information is available on the nutrient content of local species or their contributions to the ecosystem in which they are traditionally grown, they are often replaced with cash crops that can lead to uniform and vulnerable farming systems (Khoury et al., 2016). Thus, continued growth, consumption, and viable commercialisation of local biodiversity are made possible by demonstrating species' nutrition benefits to the public and government ( $\mathrm{Li}$ and Siddique, 2018). With increased research investments, it is possible to connect the limited and scattered evidence of what people are eating and how it may benefit them. This means obtaining food composition data, dietary intake data and understanding the complex pathways that link biodiversity to nutrition and health (Hunter et al., 2016). It also means collecting ecological evidence of how low-input local species can be integrated into risk-prone farming systems or agroecosystems to improve resilience to drought and other stresses (Ebert, 2014).

Two overarching activities have led the work of BFN to collect and disseminate evidence:

1. Assess nutritional value of agrobiodiversity and associated traditional knowledge in ecosystems in the four project countries.

2. Develop national portals on local foods, containing databases on nutritional properties of agrobiodiversity and associated traditional knowledge, and link to relevant national and global nutritional databases.

This includes determining a baseline status of the community and documenting food-associated information such as nutrition content in local species (see example from Turkey in Table 2), indigenous knowledge, health status and development, dietary diversity, sustainable use practices for agricultural biodiversity as well as documenting the loss of options for food and nutrition security resulting from the degradation of ecosystems and biodiversity.

Within countries, there will usually be one of more agrobiodiversity nutritional data holders, which can serve as platforms for the information collected for the local crop species. Developing collaborative agreements with these is useful for information access, sharing and exchange. Global data holders such as FAO/INFOODS - the International Network of Food Data Systems monitored by the Food and Agriculture Organization of the United Nations - are effective channels to the broader agriculture and food community.

\section{Surveying priority species in Turkey}

In Turkey, shifting food habits have been detrimental both for dietary and cultural diversity, as well as a missed economic opportunity for many families (Karabak, 2017). Previous publications associated with BFN-Turkey studied the properties of wild edible species (Cinar et al., 2017; Guzelsoy et al., 2017). Selection of these priority species involved a long process, which begun with market surveys in rural and urban settings in three geographically distinct locations: the Black Sea, Mediterranean and Aegean Region (Ozbek et al., 2017; Tugrul Ay et al., 2017; Tan et al. 2017).

Overall 2,334 questionnaires were administered to local collectors, sellers and consumers of wild foods, leading to the identification of 43 commonly-used species, including mushrooms and landraces, for further research. Samples were collected from market settings and from the wild, and food composition (Güzelsoy et al., 2017) and antioxidant activity (Ayas et al., 2017) analyses carried out.

A custom-made sustainability index (Table 3 ) was used to select the most promising among the 43 species. Each species was evaluated in accordance to criteria including their environmental, economic and food and nutrition sustainability characteristics, and then ranked. Einkorn wheat (Triticum monococcum), golden thistle (Scolymus hispanicus) and foxtail lily (Eremurus spectabilis) were chosen to focus on in marketing strategies and activities to promote wild edibles in Turkey. 
D. BELTRAME, E. GEE, B. GUNER, N. O. LAURIDSEN, W. L. G. SAMARASINGHE, V. W. WASIKE, D. HUNTER, T. BORELLI: MAINSTREAMING BIODIVERSITY FOR FOOD AND NUTRITION INTO POLICIES AND PRACTICES: METHODOLOGIES AND LESSONS LEARNED FROM FOUR COUNTRIES

Preliminary data suggests there have been increased cultivation, use and local familiarity with the crops, including an almost six-fold increase in areas devoted to the cultivation of einkorn wheat since 2013. More research is however needed to gain a complete picture of the direct impact of targeting specific wild edible species.

Data for the 43 wild edible plant species has been included in a new national portal (www.bfn-tr.org) and are accessible in the FAO/INFOODS database (Anonymous, 2017e).

Table 2. Comparison of the proximate composition and mineral element content of the edible parts of the cultivated and wild samples of einkorn wheat, fennel, cowpea and caperberries. Significant differences are highlighted.

\begin{tabular}{|c|c|c|c|c|c|c|c|c|c|}
\hline $\begin{array}{l}\text { Type of } \\
\text { samples }\end{array}$ & $\begin{array}{l}\text { Botanical name } \\
\text { of samples }\end{array}$ & $\begin{array}{l}\text { Moisture } \\
(\mathrm{g} / 100 \mathrm{~g})\end{array}$ & $\begin{array}{c}\text { Fat } \\
(\mathrm{g} / 100 \mathrm{~g})\end{array}$ & $\begin{array}{l}\text { Protein } \\
(\mathrm{g} / 100 \mathrm{~g})\end{array}$ & $\begin{array}{l}\text { Dietary } \\
\text { fiber } \\
(\mathrm{g} / 100 \mathrm{~g})\end{array}$ & $\begin{array}{c}\text { Ash } \\
(\mathrm{g} / 100 \mathrm{~g})\end{array}$ & $\begin{array}{c}\text { Zinc } \\
(\mathrm{g} / 100 \mathrm{~g})\end{array}$ & $\begin{array}{c}\text { Iron } \\
(\mathrm{g} / 100 \mathrm{~g})\end{array}$ & $\begin{array}{l}\text { Calcium } \\
(\mathrm{g} / 100 \mathrm{~g})\end{array}$ \\
\hline Landrace & Triticum monocoсcum & 10.96 & 1.83 & 9.86 & 9.72 & 0.98 & 5.00 & 3.89 & 32 \\
\hline Cultivated & Triticum durum* & 11.80 & 3.95 & 12.08 & 6.79 & 1.03 & 1.05 & 0.98 & 19 \\
\hline Wild & Foeniculum vulgare & 88.39 & 0.25 & 2.15 & 3.60 & 1.81 & 0.36 & 2.34 & 270 \\
\hline Cultivated & Foeniculum vulgare* & 84.70 & 0.39 & 3.86 & 4.58 & 2.27 & 0.59 & 11.11 & 243 \\
\hline Landrace & Vigna unguiculata & 9.28 & 1.52 & 21.57 & 33.50 & 3.48 & 3.34 & 5.56 & 108 \\
\hline Cultivated & Vigna unguiculata* & 10.22 & 1.01 & 22.88 & 18.98 & 3.18 & 4.13 & 7.43 & 87 \\
\hline Wild & Capparis spinosa & 80.58 & 0.52 & 4.10 & 4.29 & 1.09 & 0.78 & 1.19 & 121 \\
\hline Cultivated & Capparis spinose ${ }^{* *}$ & 82.70 & 0.84 & 3.35 & 3.13 & 1.09 & - & 0.54 & - \\
\hline
\end{tabular}

Source: * Anonymous, 2014b; ** Ozcan, 1999.

Table 3. The Sustainable Index. The Index takes into account a number of criteria including the environment, economic and food and nutrition sustainability characteristics of each species. This index can be used to identify suitable species for further marketing.

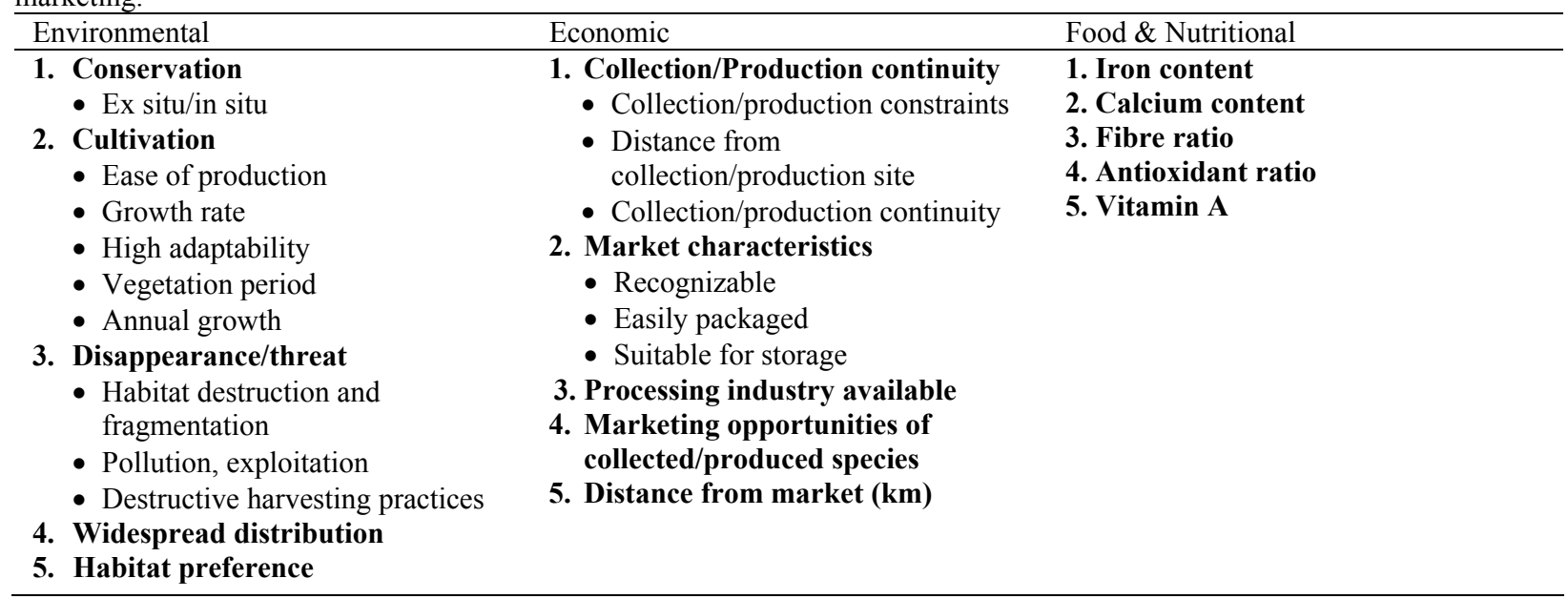

\section{Species identification and selection in Brazil}

Although native edible plants are recognized as regionally and locally important in Brazil, agricultural production in the last three decades has focused on the cultivation and trade of introduced plant species, resulting in mass clearing of the precious and highly diverse rainforest system (Anonymous, 2015c).

Led by the Ministry of the Environment, in collaboration with federal universities and research organizations such as the National Institute for
Amazon Research (INPA) and the Brazilian Agricultural Research Organisation EMBRAPA (Table 1), 65 native fruit species were selected for nutritional composition analysis. These species made use of the pre-existing platform established under the Plants for the Future initiative, which: i) identifies native Brazilian flora used both locally and regionally that doesn't currently fulfil its economic potential; ii) promotes the use of these native plant species by farmers and agricultural producers, and iii) creates an enabling environment for increased investment opportunities and 
business creation to drive the development of new marketable local products (Anonymous, 2018c). As of now, food composition analysis of more than 180 foods derived from 78 native species was generated from a review of published literature and laboratory analyses. Portfolios with general information on native edible species of fruits and vegetables are being included in the Plants for the Future book series to further share this wealth of knowledge. In addition, involved students and research partners act as multipliers within education and research institutions, building human capacity and operating as opinion leaders and policy advisors (Beltrame et al., 2016).

Food composition data and recipes generated by the BFN Project in Brazil are hosted in the Biodiversity Food Composition Database as part of the Information System on Brazilian Biodiversity $(\mathrm{SiBBr})$ created by the Ministry of Science, Technology and Innovation to gather information on Brazilian biodiversity and ecosystems currently scattered across databases in various government agencies and sources. Making this information available helped strengthen the inclusion of nutritious species in public policies and programs focused on food security and nutrition including public procurement and school feeding. (Hunter et al., 2016).

\section{Influencing policy}

A significant value of the evidence collected is that it can be used to influence policymakers, with the aim of building cross-sectorial policy frameworks and markets that support mainstreaming biodiversity conservation and sustainable use across sectors. This policy support is vital to building biodiversity capacity and encouraging species use across the production-consumption spectrum. Activities can be divided into three main types:

1. Establish cross-sectorial national policy platforms for mainstreaming agricultural biodiversity conservation and sustainable use into nutrition, health and education programmes.

2. Develop national and international policy guidelines and recommendations that promote the mainstreaming of agricultural biodiversity conservation and sustainable use into nutrition, health and education.

3. Identify and develop new marketing options for biodiversity foods with high nutritional value.

Depending on each country's context, there are varying pathways (such as nutrition, health, and education programmes) that have offered effective ways of supporting conservation and sustainable use of biodiverse species. Influencing policy can take place on different levels from national to regional policies, with prime focus given to National Biodiversity Strategy and Action Plans (NBSAPs), which reflect the individual country's vision for biodiversity and the policy, institutional measures and concrete actions that the country has taken or/and will take to fulfil the objectives of the CBD (Anonymous, 2018b).

\section{Building off a policy framework in Brazil}

BFN Brazil took advantage of existing crosssectorial governance mechanisms that were created or strengthened under the Zero Hunger Strategy framework. Four existing public policies-the Food Acquisition Program (PAA), the National School Meals Program (PNAE), the National Food and Nutrition Policy (PNAN) and the Minimum Price Guarantee Policy for Biodiversity Products (PGPM-Bio)-benefitted from data on the nutritional value of native biodiversity and provided entry points for improving nutrition (Hunter et al., 2016).

The Ministry of the Environment led the revision of Brazil's NBSAP, engaging 400 participants from institutions across the business, environment, academia, federal and state government sectors as well as indigenous peoples and traditional communities to define twenty National Biodiversity Targets for the period 2011-2020 that were closely linked to the Aichi Targets of the CBD. Some of the activities within the NBSAP now include the utilisation of native plant species with actual or potential economic value as a successful measure of biodiversity conservation (Anonymous, 2016f). 
D. BELTRAME, E. GEE, B. GUNER, N. O. LAURIDSEN, W. L. G. SAMARASINGHE, V. W. WASIKE, D. HUNTER, T. BORELLI: MAINSTREAMING BIODIVERSITY FOR FOOD AND NUTRITION INTO POLICIES AND PRACTICES: METHODOLOGIES AND LESSONS LEARNED FROM FOUR COUNTRIES

In May 2016, after extensive advocacy and lobbying by the BFN Project and Plants for the Future, Ordinance $\mathrm{N}^{\mathrm{o}} 163$ on Sociobiodiversity was published in the Union Official Journal of Brazil. Signed by both the ministers of Environment and Social Development, this Ordinance clearly articulates what defines sociobiodiversity. In July 2018, Ordinance $\mathrm{N}^{\mathrm{o}} 284$ replaced the earlier ordinance and brought the total number of neglected and underutilised species listed under "Brazilian Sociobiodiversity Native Food Species of Nutritional Value" to 100. Sociobiodiversity is defined in the Brazilian Ordinance $\mathrm{N}^{\circ} 284$ as the 'interrelation between biological diversity and the diversity of socio-cultural systems (Anonymous, 2018c). The ordinance contributes to better understanding and dissemination of knowledge on these species, which ultimately enhances their promotion and sustainable use (Hunter et al., 2016).

\section{Busia socio-biodiversity conservation policy process in Kenya}

Kenya is one of the many countries in sub-Saharan Africa where political, administrative, and financial decentralisation is taking place, creating opportunities to mainstream biodiversity at the local level (Hunter et al., 2016). Unlike in Brazil, Kenya did not have a pre-existing national policy framework and BFN project partners faced obstacles to biodiversity mainstreaming including fragmented government ministries and limited funds. Therefore, it was necessary to strengthen and build off receptive parties at the local level, identifying strategic entry points into government that could assist in the policy development process. This meant approaching government ministry members who were receptive to indigenous crop integration, or traditional dietary health practices, and using them as "champions" who could convene other influential policymakers. The BFN Project worked closely with stakeholders from Busia County in Western Kenya to develop a Biodiversity Conservation Policy that takes into account the importance of conserving nutrient-rich traditional foods such as cowpea leaves (Vigna unguiculata), amaranth (Amaranthus spp.), slender leaf (Crotalaria brevidens) and spider plant (Cleome gynandra) to increase diet quality and access to key micronutrients, particularly for mothers and children. The cross-sectoral process culminated in the March 2018 endorsement of the Busia's Biodiversity Conservation Policy, the first of its kind across Kenya's 47 counties (Anonymous, 2016g). The policy recognises the importance of traditional foods for nutrition and food security. It has allocated resources to conserve regional food biodiversity, with specific provisions for designated conservation areas and further incorporation of native species into school meals as well as linking smallholder farmers to institutional markets.

This success was only possible through concerted effort that brought together multiple parties, and engaged public stakeholder groups as well as highlevel officials including a team of experts from the County Ministries of Agriculture, Health, Education, Environment, Public Health and Forestry, the Kenya Agricultural and Livestock Research Organisation and members of the local community-based and farmer training organisation Sustainable Income Generating Investment (SINGI).

\section{Awareness}

The goal of raising awareness is to build immediate and long-term capacity for biodiversity, as more people need to recognise the value of local species before they are willing to produce, consume, and invest in them. Local stigmas that regard native species as food for the poor, or to be eaten out of necessity in times of famine, contribute to their depreciation (Kepe, 2008) and must be overcome with cultural sensitivity. For policymakers and institutions, strong evidence must be shared that demonstrates tangible benefits of investing in biodiversity. Thus, raising awareness necessitates mobilising channels on different levels, with activities that can be adapted to country-specific contexts. These include:

Assess and identify a set of best practices for mobilising biodiversity relevant to the context of the country in which it is applied.

Enhance capacity of producers, processors, users and researchers to deploy and benefit from nutritionally relevant biodiversity. 
Conduct national information campaigns/events that foster greater appreciation of biodiversity as a resource for development and wellbeing

Develop guidelines for improved use of nutrient-rich foods from local biodiversity, including processing, food safety measures, and recipes adapted to modern lifestyles based on traditional food systems.

Upscale and disseminate tools and methods for mainstreaming biodiversity into food and nutrition strategies.

Depending on the country, best practices may include gastronomic festivals, nutritional quality documentation, home and school gardens, school meal programmes, demonstration sites, value-adding, promotion, or education activities.

\section{Alaçatı herb festival}

In Turkey's Aegean Region, wild edible plants still play a major role in people's diets and are an important source of income for rural households, especially women (Karabak, 2017). Each year the Alaçatı Herb Festival, at its ninth edition in 2018, gathers thousands of visitors to celebrate the benefits of wild edible plants, and support local cuisines and food cultures based on this biodiversity. Nature walks and competitions for all ages are organized, rewarding the gatherer of the highest number of edible plants while helping scientists gather information on the traditional use of each species. 111 species and sub-species are reportedly consumed in the region while more have yet to be identified (Tan and Taskin, 2011). The involvement of celebrity chefs during the festival has also helped popularize wild edible plants among younger generations.

\section{Online mainstreaming biodiversity course}

As part of a global activity carried out by Brazil, BFN designed a training module on best practices for mobilising biodiversity to improve dietary diversity. The interactive e-learning modules take examples from all target countries to offer experiences and lessons, which can be adapted for use in nutrition and health programs. The audience includes policy makers, researchers, university professors, graduate or undergraduate students, nutritionists, extension workers or other professionals interested in biodiversity conservation, sustainable agriculture, nutrition and socio-economic development (find e-learning course here: http://www.b4fn.org/e-learning/).

\section{Hela Bojun and markets in Sri Lanka}

Under the brand name "Hela Bojun- True Sri Lankan taste", 17 market outlets for the sale of traditional foods have empowered rural women across Sri Lanka to earn a living while conserving and protecting biodiversity and making healthy food available at competitive prices. Women enrolled in the programme were trained by the Women Farmers Extension Program of the Department of Agriculture and tutored on the nutritional value of traditional foods, food preparation and food safety. The resulting restaurants and adjoining shops in Colombo and Peradeniya have become highly popular, and the women working at Hela Bojun have become the main breadwinners in their families, earning \$600800 a month. The initiative also created market demand for traditional foods such as honey, jaggery, treacle, bananas and organic products and boosted production for smallholders. The shops promote underutilised crops identified by BFN Sri Lanka, including medicinal plants such as water lily (Nymphaea pubescens), used in Ayurvedic medicine, and pulses such as cowpea (Vigna unguiculata), black gram (Vigna mungo) and green gram (Vigna radiata), as well as traditional rice varieties (Oryza spp.).

Linked to Hela Bojun, Wayamba University pilot tested cooking demonstrations with locally available greens to raise awareness of nutrition, hygiene, and food safety, and encourage the cultivation of diverse home gardens. Drawing on BFN's research, nutrition facts have been published for 91 traditional/local dishes at the Hela Bojun centres.

\section{Farmer business school in Kenya}

Instructed by local partner organisation SINGI, 4000 Kenyan farmers were trained on traditional crops' nutritional value and sustainable cultivation strategies, including techniques such as mandala, 
D. BELTRAME, E. GEE, B. GUNER, N. O. LAURIDSEN, W. L. G. SAMARASINGHE, V. W. WASIKE, D. HUNTER, T. BORELLI: MAINSTREAMING BIODIVERSITY FOR FOOD AND NUTRITION INTO POLICIES AND PRACTICES: METHODOLOGIES AND LESSONS LEARNED FROM FOUR COUNTRIES

keyhole, and multi-story gardens. Additionally, the Farmer Business School model offered trainings to entrepreneurial farmers in Busia County on contract farming, business plans as well as the ability to respond to demands from institutional markets such as local schools and clinics. This is now being trialled through a food procurement model where local farmer groups sell indigenous produce directly to school canteens that feed students and staff. A Memorandum of Understanding is drawn up between the farmer and school regulating the arrangement and, bypassing market operators, the model allows for mutually beneficial consistent pricing agreements. This model was created in response to the specific needs of small scale agricultural entrepreneurs (mostly women and youth) living in Busia County who expressed ambitions to grow their currently small enterprises by commercialising African leafy vegetables and other nutritious crops. A facilitator's training manual was developed to extend the training to other farmers and community-based organizations.

\section{CONCLUSION}

Although this article has outlined a general methodology focused on evidence, policy and awareness, the examples from different countries demonstrate that context determines the most effective approach to mainstreaming agrobiodiversity for nutrition. In particular, the success of activities depends on partnerships that build off pre-existing demands and opportunities. Furthermore, operating in four significantly different countries has shown to be a strength, not a weakness of the BFN Project, in fact, sharing experiences and lessons learned across countries is a critical component of the initiative.

\section{REFERENCES}

Abukutsa-Onyango, M. O. 2007. Seed Production and Support Systems for African Leafy Vegetables in Three Communities in Western Kenya. African Journal of Food Agriculture, Nutrition and Development Volume 7, No: 3. ISSN 1648-5374 (Online).

Allen, T., P. Prosperi, B. Cogill, and G. Flichman. 2014 Agricultural biodiversity, social-ecological systems and sustainable diets. Proceedings of the Nutrition Society 73 (4): 498-508.
In all countries, increased data and strong evidence of species' nutrient composition was key to the project's success. BFN's research determines further actions to take and has global relevance with contributions to the FAO/INFOODS database, in addition to national food composition tables and biodiversity strategies.

Many of the elements discussed above converge with the example of institutional procurement, as seen with school feeding in Kenya. There, an agreement was reached that simultaneously addressed consumer demand and supply constraints linked to marketing traditional crops. Formalised support, such as Busia's Biodiversity Policy or Sociobiodiversity Ordinance $\mathrm{N}^{\mathrm{o}} 284$ in Brazil, create an enabling environment that makes expansion of this model feasible. Both examples are based on the FAO Voluntary Guidelines (Anonymous, 2016h), offering a set of concrete tools for mainstreaming biodiversity into policies, programmes and national and regional plans of action with particular attention to the nutrition aspects.

As the first phase of BFN concludes (2012-18), the project is sharing methods and results, for example, at COP14 of the CBD, as well as anticipating how to adapt to further regions in the future. With support from the Australian Centre for International Agricultural Research (ACIAR) BFN intends to initiate more rigorous testing of the direct procurement model in additional schools and countries where it is possible to build off preestablished regional partnerships. This will be key in establishing a more quantitative analytical basis demonstrating the feasibility of up-scaling the growth, sale, and consumption of underutilised species. Additional evidence can also support further policy successes, and contribute to increased awareness and capacity.

Anonymous. 2006. Convention on Biological Diversity (CBD). COP 8, Decision VIII/23. Available at: https://www.cbd.int/decision/cop/?id=11037.

Anonymous. 2009. State of Brazil's plant genetic resources Second National Report. Conservation and sustainable utilization for food and agriculture. Brasília, DF, 2009, p. 29. Brazilian Agricultural Research Corporation. 
Anonymous. 2014a. Fifth National Report to the UN Convention on Biological Diversity. Ministry of Forestry and Water Affairs (MoF\&WA), Republic of Turkey.

Anonymous. 2014b. TürKomp, Turkish Food Composition Database, version 1.0. Food Institute, TÜBİTAK Marmara Research Center, Gebze / Kocaeli, 2014. Website: www.turkomp.gov.tr.

Anonymous. 2015a. Connecting global priorities, biodiversity and human health. Summary of the state of knowledge review. WHO. World Health Organization.

Anonymous. 2015b. The state of food insecurity in the world 2015. Meeting the 2015 international hunger targets: taking stock of uneven progress (FAO, IFAD and WFP). Rome, FAO.

Anonymous. 2015c. Conselho Federal de Nutricionistas. IV jornada de atualização técnica de fiscais do Sistema $\mathrm{CFN} / \mathrm{CRN}$.

Anonymous. 2016a. Food systems and diets: Facing the challenges of the $21^{\text {st }}$ Century. Global Panel on Agriculture and Food Systems for Nutrition (GPA\&FSN). London, UK.

Anonymous. 2016b. IPES-Food. From uniformity to diversity: A paradigm shift from industrial agriculture to diversified agroecological systems. International panel of experts on sustainable food systems.

Anonymous. 2016c. Convention on Biological Diversity (CBD). Brazil - Country profile - Biodiversity facts. Available at: https://www.cbd.int/countries/profile/ default.shtml? country=br.

Anonymous. 2016d. Global Nutrition Report 2016: From promise to impact: ending malnutrition by 2030 . International Food Policy Research Institute (IFPRI). Washington, D. C. USA.

Anonymous. 2016e. National biodiversity strategic action plan 2016-2022. Colombo, Sri Lanka: Biodiversity Secretariat, Ministry of Mahaweli Development and Environment (MoMD \& E).

Anonymous. 2016f. National biodiversity strategy and action plan 2016-2020. Ministry of Environment, Brazil.

Anonymous. 2016g. Busia county biodiversity policy (Our heritage, our strength and the basis of our development) 2016-2023. Busia County, Government of the Republic of Kenya, 2016.

Anonymous. 2016h. Voluntary guidelines for mainstreaming biodiversity into policies, programmes and national and regional plans of action on nutrition. Food and Agriculture organization of the United Nations (FAO).

Anonymous. 2017a. HLPE. Nutrition and food systems. A report by the High Level Panel of Experts on food security and nutrition of the committee on world food security, Rome.

Anonymous. 2017b. Global nutrition report 2017: Nourishing the SDGs. Bristol, UK: Development Initiatives.
Anonymous. 2017c. Mainstreaming agrobiodiversity in sustainable food systems: Scientific foundations for an agrobiodiversity index. Bioversity International, Rome. Italy.

Anonymous. 2017d. The state of food security and nutrition in the world 2017. Building resilience for peace and food security (FAO, IFAD, UNICEF, WFP and WHO). Rome, FAO.

Anonymous. 2017e. FAO/INFOODS Food Composition Database for Biodiversity Version 4.0 BioFoodComp4.0. FAO, Rome.

Anonymous. 2018a. Plantas para o Futuro. Ministry of Environment, Brazil. From http://www.mma.gov.br/biodiversidade/conservacaoe-promocao-do-uso-da-diversidade-genetica/plantaspara-o-futuro\#.

Anonymous. 2018b. Convention on Biological Diversity (CBD). What is NBSAP? From https://www.cbd.int/nbsap/introduction.shtml

Anonymous. 2018c. Diário official da união. Portaria Interministerial $\mathrm{N}^{\mathrm{o}} 284$ de 30 de Maio de 2018. ISSN 1677-7042. Imprensa Nacional (MoE\&MoSD).

Ayas, F., F. A. Vuran, K. Yuksel, O. Cinar, S. Tugrul Ay, and S. Karabak 2017. The Antioxidant Capacities and Consumption Per Capita of Edible Wild Species and Local Varieties Collected from Turkey within the GEF-Funded Biodiversity for Food and Nutrition (BFN) project. ANADOLU, J. of AARI 27 (2): 4653 .

Beltrame, D. M. O, C. N. S. Oliveira, T. Borelli, R. A. C. Santiago, E. S. Monego, V. V. Rosso, L. Coradin, and D. Hunter. 2016. Diversifying institutional food procurement - opportunities and barriers for integrating biodiversity for food and nutrition in Brazil. Revista Raizes 36(2) p. 55-69 ISSN: 0102$552 \mathrm{X}$

Broegaard, R. B., L. V. Rasmussen, N. Dawson, O. Mertz, T. Vongvisouk, and K. Grogan. 2017. Wild food collection and nutrition under commercial agriculture expansion in agriculture-forest landscapes. Forest Policy and Economics 84: 92-101.

Cinar, A., S. Tugrul Ay, F. Ayas, S. Karabak, N. Guzelsoy, and O. Ucurum. 2017. Foxtail lily (Eremurus spectabilis M. Bieb.) as priority species of Biodiversity for Food and Nutrition Project of Turkey. ANADOLU, J. of AARI 27(2): 69 - 73.

Dogan, Y. 2012. Traditionally used wild edible greens in the Aegean region of Turkey. Acta Societatis Botanicorum Poloniae Vol 81, No 4.

Ebert, A. W. 2014. Potential of underutilised traditional vegetables and legume crops to contribute to food and nutritional security, income and more sustainable production systems. Sustainability 6:319-335. 
D. BELTRAME, E. GEE, B. GUNER, N. O LAURIDSEN, W. L. G. SAMARASINGHE, V. W. WASIKE, D. HUNTER, T. BORELLI: MAINSTREAMING BIODIVERSITY FOR FOOD AND NUTRITION INTO POLICIES AND PRACTICES: METHODOLOGIES AND LESSONS LEARNED FROM FOUR COUNTRIES

Ertug, F. 2014. Yenen Bitkiler (Edible Plants). In: A. Güner and T. Ekim (Eds.) Resimli Türkiye florası (Illlustrated flora of Turkey). Vol. 1. Ali Nihat Gökyiğit vakfi, flora araştırmaları derneği and Türkiye İş bankası kültür yayınları, İstanbul.

França, C., M. Grossi, and V. Marques. 2009. O censo agropecuário 2006 e a agricultura familiar no Brasil. Brasília: Ministry of Agrarian Development.

Gido, E. O., O. I. Ayuya, G. Owuor, and W. Bokelmann. 2017. Consumption intensity of leafy African indigenous vegetables: towards enhancing nutritional security in rural and urban dwellers in Kenya. Agricultural and Food Economics 5: 14.

Gillespie, S., L. Haddad, V. Mannar, P. Menon, and N. Nisbett. 2013. The politics of reducing malnutrition: building commitment and accelerating progress. Maternal and child nutrition study group. Lancet 382 (9891): 552-569.

Guzelsoy, N. A., O. Uçurum , E. Tokat, A. Tan, S. Tugrul Ay, and K. Ozbek. 2017. Nutritional Properties of some Wild Edible Plant Species in Turkey. ANADOLU, J. of AARI 27 (2): 39-45.

Hajjar, R., D. I. Jarvis, and B. Gemmill-Herren. 2008. The utility of crop genetic diversity in maintaining ecosystem services. Agriculture, Ecosystems and Environment 123: 261-270.

Hunter, D., B. Burlingame, and R. Remans. 2015. Biodiversity and nutrition. In: WHO/CBD (Ed.) Connecting global priorities: Biodiversity and human health: A state of knowledge review. Geneva: WHO. 97-129.

Hunter, D., I. Özkan, D. Moura de Oliveira Beltrame, W. L. G. Samarasinghe, V. W. Wasike, U. R. Charrondière, T. Borelli, and J. Sokolow. 2016. Enabled or disabled: is the environment right for using biodiversity to improve nutrition? Front. Nutr. 3: 14

Huntley, B. J., and K. H. Redford. 2014. Mainstreaming biodiversity in practice: a STAP advisory document. Global Environment Facility, Washington, D.C. USA.

Johns, T., and P. B. Eyzaguirre. 2006. Linking biodiversity, diet and health in policy and practice. Proceedings of the Nutrition Society 65 (2): 182-189.

Jones, A. D. 2017. On-farm crop species richness is associated with household diet diversity and quality in subsistence- and market-oriented farming households in Malawi. J. Nutr.147 (1): 86-96.

Karabak, S. 2017. Economic and socio-cultural importance of edible wild species. ANADOLU, J. of AARI. 27 (2): 26-38. MFAL.

Katulanda, P., M. A. Jayawardena, M. H. Sheriff, G. R. Constantine and D. R. Matthews. 2010. Prevalence of overweight and obesity in Sri Lankan adults. Obes Rev. (11): 751-756.
Kepe, T. 2008. Beyond the numbers: understanding the value of vegetation to rural livelihoods in Africa. Geoforum 39 (2): 958-968

Khoury, C. K., A. D. Bjorkman, H. Dempewolf, J. RamirezVillegas, L. Guarino, A. Jarvis, L. H. Rieseberg and P. C. Struik. 2014. Increasing homogeneity in global food supplies and the implications for food security. Proceedings of the National Academy of Sciences of the USA 111 (11): 4001-6.

Khoury, C. K., H. A. Achicanoy, A. D. Bjorkman, C. NavarroRacines, L. Guarino, X. Flores-Palacios, J. M. M Engels, J. H. Wiersema, H. Dempewolf, S. Sotelo, J. Ramírez-Villegas, N. P. Castañeda-Álvarez, C. Fowler, A. Jarvis, L. H. Rieseberg, and P. C. Struik. 2016. Origins of food crops connect countries worldwide. Proceeding of the Royal Society B 283: 20160792.

Koppmair, S., M. Kassie, and M. Qaim. 2017. Farm production, market access and dietary diversity in Malawi. Public Health Nutrition 20 (2): 325-335.

Li, X., and K. H. M. Siddique. 2018. Future Smart Food Rediscovering hidden treasures of neglected and underutilised species for Zero Hunger in Asia. Food and Agriculture Organization of the United Nations, Bangkok, $242 \mathrm{pp}$.

Ngugi, I. K., R. Gitau, and J. K. Nyoro. 2006. Access to high value markets by smallholder farmers of African indigenous vegetables in Kenya. Tegemeo Institute, Egerton University.

Nugent, R. 2011. Bringing agriculture to the table: How agriculture and food can play a role in preventing chronic disease. Chicago council on global affairs.

Ozbek, K., S. Karabak, N. Aysar Guzelsoy, N. Sari, R. Murat Duran, R. Tasci, B. Guner, H. Yuce Arslan, D. Deniz, A. Aksoy. 2017. Biodiversity for Food and Nutrition Project: Black Sea region studies. ANADOLU, J. of AARI 27 (2): 17-25.

Ozcan, M. 1999. The physical and chemical properties and fatty acid compositions of raw and brined caperberries (Capparis spp.). Turkish journal of agriculture and forestry 23 (3): 771-776

Powell, B., S. H. Thilsted, A. Ickowitz, C. Termote, T. Sunderland and A. Herforth. 2015. Improving diets with wild and cultivated biodiversity from across the landscape. Food Security 7: 535-554.

Rajapaksha, U. 1998. Traditional food plants in Sri Lanka. Hector Kobbekaduwa agrarian research and training institute, Sri Lanka.

Remans, R., and S. Smukler. 2013. Linking biodiversity and nutrition. In: J. Fanzo et al. (Eds). Diversifying foods and diets: using agricultural biodiversity to improve nutrition and health. Routledge, 140-163.

Remans, R., D. F. Flynn, F. DeClerck, W. Diru, J. Fanzo, K. Gaynor, I. Lambrecht, J. Mudiope, P. K. Mutuo, P. Nkhoma, D. Siriri, C. Sullivan, and C. A. Palm. 2011. Assessing nutritional diversity of cropping systems in African villages. PLoS ONE 6 (6): e21235. 
Romeo, A., J. Meerman, M. Demeke, A. Scognamillo and S. Asfaw. 2016. Linking farm diversification to household diet diversification: evidence from a sample of Kenyan ultra-poor farmers. Food Security 8 (6): 1069-1085.

Sekercioglu, C. H., S. S. Anderson, E. Akcay, R. Bilgin, O. Emre Can, G. Semiz, C. Tavsanoglu, M. B. Yokeş, A. Soyumert, K. Ipekdal, I. K. Sağlam, M. Yucel, and H. N. Dalfes. 2011. Turkey's globally important biodiversity in crisis. Biological Conservation 144: 2752-2769.

Stöber, S., W. Chepkoech, S. Neubert, B. Kurgat, H. Bett, and H. Lotze-Campen. 2016. Adaptation pathways for African indigenous vegetables' value chains. pp. 2123. In Filho et al. (Eds) Symposium on climate change adaptation in Africa "Fostering African resilience and capacity to adapt", Addis Ababa, Ethiopia.

Tan, A. 2010. Second national report of Turkey on Conservation and Sustainable Utilisation of Plant Genetic Resources for Food and Agriculture on conservation and sustainable utilization of plant genetic resources for food and agriculture, AARI Pub. No: 141. Meta Basim. Bornova.
Tan, A., N. Adanacioglu, S. Karabak, L. Aykas, N. Tas, and T. Taylan. 2017. Biodiversity for Food and Nutrition: Edible wild plant species of Aegean region of Turkey. ANADOLU, J. of AARI 27 (2): 1-8.

Tan, A., and Taskin. T. 2011. Some edible wild plants of Turkey and their use. Transaction of the international scientific conference "Actual problems in the use of useful plants". Proceedings. 26-28. Oktober 2011. Bakü, Azerbaijan.

Tugrul Ay, S., A. Cinar, F. Ayas, K. Yuksel, O. Cinar, and S. Karabak. 2017. Mediterranean Region Studies of Mainstreaming Biodiversity Conservation and Sustainable Use for Improved Human Nutrition and Wellbeing Project. ANADOLU, J. of AARI 27 (2): 916 